\title{
CONVENÇÕES PROCESSUAIS ATÍPICAS NA EXECUÇÃO CIVIL ${ }^{1}$
}

\section{PROCEDURAL AGREEMENTS IN BRAZILIAN CIVIL ENFORCED EXECUTION}

Fernando da Fonseca Gajardoni

Professor Doutor de Direito Processual Civil da Faculdade de Direito de Ribeirão Preto da USP (USP/FDRP). Doutor e Mestre em Direito Processual pela Faculdade de Direito da USP (USP-FD). Juiz de Direito no Estado de São Paulo desde 1998. Ribeirão Preto/SP. E-mail: fernando.gajardoni@ usp.br

RESUMO: O presente estudo analisa as condições e limites de cabimento das convenções processuais atípicas no âmbito da execução civil (art. 190 do CPC). Trata, também, da controvérsia sobre o cabimento das convenções processuais para afastar a impenhorabilidade do bem de família legal ou dos vencimentos do devedor, bem como dos negócios processuais de desjudicialização da execução civil e de admissão de medidas executivas atípicas convencionais.

PALAVRAS-CHAVE: Convenções processuais. Execução civil. Bem de família. Vencimentos. Desjudicialização da execução civil. Medidas executivas atípicas.

ABSTRACT: The present study analyzes the conditions and limits for the procedural agreements in brazilian enforced execution (art. 190 CPC). It also deals with the controversy about the possibility to remove protection of "legal family property" (bem de família) or the debtor's salary by procedural agreements, and the appropriateness of procedural settles to dejudicialization enforced civil execution and to deal atypical conventional executive measures.

\footnotetext{
${ }^{1}$ Artigo recebido em 05/10/2020 e aprovado em 13/12/2020.
} 
KEY WORDS.: Civil procedural law. Procedural agreements. Civil enforced execution. Dejudicialization.

\section{Introdução}

O publicismo processual e, por conseguinte, o ideário de cogência das normas processuais e procedimentais, fizeram com que a doutrina não se interessasse muito pelo estudo dos negócios jurídicos processuais no regime processual revogado ${ }^{2}$. Alguns autores, inclusive, negaram a existência de contratos em matéria processual, sob o fundamento de que a vontade dos sujeitos processuais não determina os efeitos dos atos processuais que praticam, não havendo, por isso, discricionariedade para que elas possam convencionar a respeito $^{3}$. Mesmo os que aceitavam a existência de convenções processuais aduziam que não se poderia emprestar à vontade da parte no processo civil a mesma importância que tem no direito privado, eis que no processo "há sempre um elemento especial a considerar, e é a presença do órgão do Estado sobre a atividade do qual, se bem que estranho ao negócio, pode ele exercer influência mais ou menos direta"4.

O CPC/1973, contudo, não desconsiderava a vontade das partes no processo. Tomando como referência a norma processual que se almejava relativizar (e não a natureza do direito material em conflito), até havia alguns temas - todos relativos a normas processuais não cogentes - em que o CPC/1973 admitia a celebração de negócios jurídicos bilaterais típicos pelas partes. A eleição de foro (art. 111 do CPC/1973), a suspensão voluntária do processo (art. 265, II, CPC/1973), a convenção sobre ônus da prova (art. 333, parágrafo único, CPC/1973), o adiantamento da audiência por convenção das partes (art. 453, I, CPC/1973) e a convenção de arbitragem (art. 267, VII, CPC/1973 e art. 3. ${ }^{\circ}$ da Lei n. ${ }^{\circ}$ 9.307/1996), entre outros, são exemplos sempre lembrados. Ampliado o espectro de abrangência do negócio jurídico processual para abarcar, também, os atos unilaterais (negócios jurídicos unilaterais), o CPC/1973 também considerava relevante a vontade para

\footnotetext{
${ }^{2}$ MOREIRA, José Carlos Barbosa. Convenções das partes em matéria processual. Temas de direito processual civil: terceira série. São Paulo, Saraiva, 1984, p. 87/98.

${ }^{3}$ ROCHA, José Albuquerque. Teoria geral do processo. $3^{a}$ ed. São Paulo: Malheiros, 1996, p. 253 e ss.

${ }^{4}$ CHIOVENDA, Giuseppe. Instituições de Direito Processual Civil. Traduzido por Paolo Capitano. Campinas: Bookseller, 1998c v 3, p. 25-26.
} 
admitir a desistência do processo (art. 267, VIII), o reconhecimento jurídico do pedido (art. 269, II), a renúncia ao recurso (art. 502), a renúncia ao direito sobre o qual se funda a ação (art. 269, V), a escolha do juízo da execução (art. 475-P) etc.

Entretanto, de modo atípico (genérico) - isto é, sem que houvesse previsão legal expressa reconhecendo os efeitos da específica manifestação de vontade ou da inércia das partes -, a vontade dos litigantes era irrelevante para a definição do modo de ser do processo civil no regime revogado.

Poucos no Brasil foram aqueles que, antes de qualquer cogitação a respeito de um Novo CPC, se arriscaram a sustentar, de lege ferenda, a necessidade e a possibilidade de a vontade das partes, por meio de negócios bilaterais atípicos (convenções processuais), influir no curso do processo e do procedimento:

\begin{abstract}
"se por um lado, como regra, as normas processuais no todo (incluídas as procedimentais) são de ordem pública e, como tal, de observância obrigatória por todos os atores processuais - com o que não discordamos em princípio - por outro, inúmeras situações ligadas ao direito material, à realidade das partes, ou simplesmente à inexistência de prejuízo, devem permitir a eleição do procedimento, inclusive pelas próprias partes (...) Seria interessante, de lege ferenda, ampliar a possibilidade de as partes celebrarem negócio jurídico processual quanto ao prazo processual. Se aos litigantes interessa, precipuamente, a resolução do conflito, pareceme que devem ter eles autonomia, também, para consensualmente estabelecer o curso do procedimento ou de parcela dele, nos moldes do que já ocorre em sede arbitral"s.
\end{abstract}

O CPC/2015, de modo bastante inovador e sem equivalente exato em direito comparado, rompe a dogmática até então reinol, e, mediante uma cláusula geral de negócio jurídico processual, passa a admitir que a vontade das partes, por meio de negócios jurídicos processuais bilaterais atípicos (não disciplinados casuisticamente em lei), tenha impacto no procedimento e na relação jurídica processual estabelecida em lei. O art. 190 dispõe que:

\footnotetext{
"versando o processo sobre direitos que admitam autocomposição, é lícito às partes plenamente capazes estipular mudanças no procedimento para ajustá-lo às especificidades da causa e convencionar sobre os seus ônus, poderes, faculdades e deveres processuais, antes ou durante o processo".
}

\footnotetext{
${ }^{5}$ GAJARDONI, Fernando da Fonseca. Flexibilização procedimental: um novo enfoque para o estudo do procedimento em matéria processual. São Paulo: Atlas, 2007, p. 215 e ss.
} 
O impacto no publicismo processual é evidente, uma vez que, em substituição à lei, as partes passam a ter poder e autonomia para definir o modo de ser do processo civil. Se não é posto literalmente em xeque o ideário de um processo civil público e com regras cogentes e inderrogáveis pela vontade das partes, ao menos se mitiga o rigor do publicismo processual (ou do hiper-publicismo) ${ }^{6}$, inaugurando-se no direito processual brasileiro uma fase de neoliberalismo processual, que, embora incapaz de tornar o processo "coisa das partes", como no período da litiscontestatio romana (ordo judiciorum privatorum) ${ }^{7}$, abala a estrutura de um sem-número de institutos processuais, doravante com regramento manipulável pelos litigantes.

Mantém-se, de todo modo, a disciplina dos negócios jurídicos processuais típicos (tal como no CPC/1973), isto é, previstos expressa e particularmente em lei. Continuam a existir os negócios processuais bilaterais típicos, tais como foro de eleição (art. 63), suspensão do processo por vontade das partes (art. 313, II), convenção sobre ônus da prova $\left(373, \S 3 .^{\circ}\right)$, convenção de arbitragem (art. 485, VII) etc. Continua relevante a manifestação de vontade (ou a inércia da parte) no tocante aos negócios jurídicos processuais unilaterais e plurilaterais típicos, como na sucessão do alienante ou cedente pelo adquirente ou cessionário da coisa litigiosa (art. 109), na desistência do recurso (art. 998), no reconhecimento jurídico do pedido (art. 487, III, “a”), na renúncia ao recurso (art. 999) ou ao direito sobre o qual se funda a ação (art. 487, III, “c”) etc. E introduziram-se, ainda, mais alguns negócios processuais típicos não previstos no CPC/1973, entre os quais se destacam a convenção de escolha do perito (art. 471) e a calendarização (art. 191).

Têm-se no CPC/2015, portanto, dois modelos de negócios jurídicos processuais: a) os atípicos ou inominados, previstos no art. 190 do CPC (sempre bilaterais); e b) os típicos ou nominados, encontrados em dispositivos esparsos e específicos do CPC (estes bilaterais, unilaterais ou plurilaterais).

\section{Condições de validade dos negócios jurídicos processuais bilaterais e atípicos}

\footnotetext{
${ }^{6}$ CABRAL, Antonio do Passo. Convenções processuais. Tese de livre docência. Faculdade de Direito da USP, 2015, p. 101 e ss.

${ }^{7}$ TUCCI, José Rogério Cruz e; AZEVEDO, Luiz Carlos de. Lições de história do processo civil romano. São Paulo: RT, 2001, p. 98.
} 
Os negócios jurídicos processuais bilaterais, como espécie de negócios jurídicos, submetem-se, com as devidas adaptações, ao regime jurídico destes (arts. 104 e seguintes do CC). Logo, para a validade das convenções sobre processo celebradas antes ou non curso dele (que nada mais são dos negócios jurídicos aplicados ao direito processual), é necessário que: a) as partes sejam capazes; b) o objeto seja lícito; c) a forma seja a prescrita ou não defesa em lei; e d) que seja respeitada a autonomia da vontade das partes celebrantes, tal como em qualquer negócio jurídico.

Além deste primeiro grupo de condições (condições gerais), há, ainda, as condições específicas de validade dos negócios jurídicos processuais: a) partes plenamente capazes; e b) direito autocomponível; condições derivadas da própria disciplina do tema no CPC (art. 190, caput).

São dois, portanto, os grupos de condições de validade dos negócios jurídicos processuais atípicos: condições gerais (no total de 04) e condições específicas (no total de 02).

A definição destas 06 (seis) condicionantes é fundamental para a própria compreensão dos negócios jurídicos processuais, em especial em tema de execução civil. Não se nega que há controvérsias a respeito na doutrina brasileira, ou mesmo que a extensão que se dá a tais condicionantes é determinante para se admitir ou não determinados negócios jurídicos processuais atípicos. Porém, é uniforme o entendimento de que referidas condicionantes se aplicam a todo e qualquer negócio pré-processual ou processual atípico, sejam eles celebrados no processo de conhecimento, nos processos de urgência (antecedentes) ou na execução civil.

\subsection{Capacidade do agente e o limitador semântico "seus" do art. 190, caput, do CPC}

A capacidade das partes é a genérica, para a prática de atos jurídicos em geral (art. 2. ${ }^{\circ}$ do CC), isto é, negócios processuais devem ser celebrados por seres humanos (art. 104, I, e 166 do CC).

$\mathrm{Na}$ verdade, quando se estabelece, como condição geral dos negócios jurídicos processuais, a capacidade do agente, deve se focalizar o fato de que, como regra, só é agente capaz aquele que tenha a capacidade de disposição de seu próprio direito. Não é capaz de convencionar direitos, ônus, obrigações, faculdades etc., aquele que não seja seu titular. 
Por vedação legal específica (art. 190, caput, CPC) - e não do regime dos negócios jurídicos em geral -, entendemos não ser possível às partes incapazes (arts. 3. ${ }^{\circ}$ e.$^{\circ}$ do CC), mesmo que assistidas ou representadas, celebrarem negócio processual. O interesse público recomendou, tanto quanto recomenda no art. $1 .^{\circ}$ da Lei n. ${ }^{\circ}$ 9.307/1996 (Lei de Arbitragem), que a situação jurídica do incapaz, inclusive processual, seja preservada conforme as regras legais, limitando-se, por conseguinte, a autonomia de sua vontade (na verdade exercitável pelo seu representante/assistente). Tanto que a lei condiciona a celebração de convenção por partes plenamente capazes, isto é, que não estejam a depender de interposta pessoa para o exercício de seus direitos processuais (capacidade ad processum). A plenitude da capacidade das partes para celebrar a convenção, portanto, não é uma condição genérica de validade do negócio; é uma condição específica (vide item 2.6 infra).

A afirmação não é meramente acadêmica e tem enormes efeitos práticos, pois que sendo o processo (e suas normas) uma relação jurídica de direito público, há situações jurídicas que são apenas das partes, e outras que são titularizadas pelo Estado e por terceiros. Este segundo grupo não pode ser objeto de convenção pelas partes, exatamente por falta de poder de disposição das partes sobre posições jurídicas alheias (incapacidade do agente).

Tanto que consta expressamente do art. 190 do CPC um limitador semântico bastante claro (e ignorado por parcela hiperprivatista da doutrina): "é lícito às partes plenamente capazes estipular mudanças no procedimento para ajustá-lo às especificidades da causa e convencionar sobre os seus ônus, poderes, faculdades e deveres processuais".

Este "seus" constante do art. 190, caput, do CPC, reafirma a incapacidade de as partes celebrarem convenções que: a) afetem situações jurídicas de terceiros (v.g., vedando que terceiros possam requerer o ingresso no processo na condição de assistentes, na forma do art. 119 do CPC; retirando dos advogados da ação a titularidade sobre os honorários de sucumbência arbitrados pelo juiz, em desconformidade com o art. 85, § 14, do CPC; etc); ou b) subtraiam deveres, poderes e obrigações cogentes do Estado-juiz (como o de sancionar a litigância ímproba na forma dos artigos 77, 80 e 81 do CPC, ou determinar oficiosamente a produção de provas, na forma do art. 370 do CPC).

Conforme veremos adiante, será exatamente pela incapacidade de disposição de direitos alheios que não será possível - ao menos sem a participação de toda a família na 
pactuação -, convenção processual atípica para admissão da penhora do bem de família (art. $1^{\circ}$ da Lei 8.009/90) fora das hipóteses previstas no art. $3^{\circ}$ da Lei 8.009/90.

\title{
2.2. Objeto lícito
}

Não é válido negócio jurídico processual bilateral atípico com objeto ilícito (arts. 104, II, e 166, CC) como os que, exemplificativamente, se prestem a afastar a incidência das garantias do devido processo constitucional (legal).

\begin{abstract}
"Situadas no âmbito constitucional, as garantias constitucionais do processo se mostram como fundamento de validade das normas do Código de Processo Civil que, por sua vez, dão fundamento de validade para eventuais 'contratos processuais'. Nesse sentido, não seria possível conceber que estes 'contratos processuais', no mais baixo nível de escalonamento, teriam autorização para ignorar as diretrizes gerais previstas na Constituição (de natureza imperativa) quanto à forma de desenvolvimento e os resultados do processo (devido processo legal)" $"$.
\end{abstract}

Assim, convenções tendentes a (i) dispensar o dever de motivação das decisões judiciais; (ii) a suprimir o contraditório ou o direito de defesa; (iii) a impor o segredo de justiça no trâmite do processo; (iv) a admitir a validade de prova ilícita; ou (v) disciplinar, de modo diverso da $\mathrm{CF}$, regras de competência por prerrogativa de função e/ou viabilizadoras do juiz natural (v.g., escolhendo previamente a instância onde teria início a causa); têm objeto ilícito e, como tal, são nulas de pleno direito.

Aplica-se, aqui, a limitação constante tanto da lei civil (art. 2.035, parágrafo único, CC) quanto da Lei de Arbitragem (arts. 2. ${ }^{\circ}$, $1 .^{\circ}$, e 21, § 2. ${ }^{\circ}$, da Lei n. ${ }^{\circ} 9.307 / 1996$ ), no sentido de que são nulas as convenções cujo teor viole as garantias constitucionais do processo, os costumes e a ordem pública.

Neste sentido, a Escola Nacional de Formação de Magistrados (ENFAM) editou

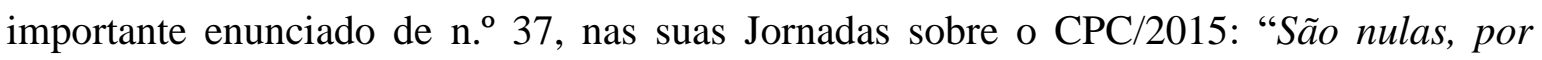
ilicitude do objeto, as convenções processuais que violem as garantias constitucionais do processo, tais como as que: a) autorizem o uso de prova ilícita; b) limitem a publicidade do

\footnotetext{
${ }^{8}$ MACHADO, Marcelo Pacheco. A privatização da técnica processual no projeto do Novo Código de Processo Civil. In: Alexandre Freire et al. Novas tendências do processo civil - estudos sobre o projeto do Novo CPC. Salvador: Juspodvm, 2014, v. 3, p. 339-362.
} 
processo para além das hipóteses expressamente previstas em lei; c) modifiquem o regime de competência absoluta; e d) dispensem o dever de motivação".

\subsection{Forma prescrita ou não defesa em lei}

No tocante à forma da convenção, que deve ser a prescrita ou não vedada em lei (arts. 104, III, e 166, do CC), não se observa disposição legal a estabelecê-la. Certamente se cogitará que há liberdade na forma da convenção, que pode ser celebrada, inclusive, de modo oral.

Contudo, a falta de parâmetros seguros para o desenvolvimento do processo em juízo é fator absolutamente indesejável, dando ensejo a conflito paralelo e preliminar sobre quais serão as regras processuais avençadas a permitir a solução do conflito de fundo.

Quer parecer, assim, que o parâmetro mínimo da convenção processual é que ela seja escrita (ainda que apresentada oralmente nos autos do processo e reduzida a termo), aplicando-se integrativamente o disposto nos arts. $63, \S 1 .^{\circ}$, do CPC e $4 .^{\circ}, \S 1 .^{\circ}$, da Lei de Arbitragem (Lei n. ${ }^{\circ}$ 9.307/1996).

Valores como previsibilidade e segurança jurídica, inclusive por serem decorrentes da cláusula do devido processo legal, devem prevalecer sobre tese em sentido contrário pela admissão de convenções orais (especialmente pré-processuais).

A interpretação aqui defendida também foi objeto de enunciado interpretativo da ENFAM, de número 39: "Não é válida convenção pré-processual oral (art. 4. ${ }^{\circ}$ \& 1. , da Lei n. 9.307/1996 e 63, § 1. ${ }^{\circ}$, do CPC)".

\subsection{Preservação da (autonomia) da vontade dos contratantes}

Além da licitude dos elementos gerais do negócio jurídico (agente, objeto e forma), é necessário, ainda, que se preserve a autonomia da manifestação de vontade das partes, invalidando as convenções celebradas com vícios de vontade ou sociais, na forma dos arts. 138, 165 e 171 do CC.

Prova disso é que o art. 190, parágrafo único, do CPC, admite o controle pelo juiz da validade das convenções processuais, recusando-lhes aplicação nos casos de nulidade ou de inserção abusiva em contrato de adesão ou em que alguma parte se encontre em manifesta situação de vulnerabilidade. Nestas duas últimas situações (inserção abusiva em contrato de 
adesão e parte em situação de vulnerabilidade), está-se a tutelar, exatamente, a livre manifestação de vontade, sem a qual a convenção não pode ter efeitos.

Diversamente do regime legal dos negócios jurídicos em geral, observado o vício na emissão de vontade por conta da inserção abusiva da convenção em contrato de adesão ou da vulnerabilidade do celebrante, o juiz pode pronunciar de ofício a nulidade da convenção processual, conforme, aliás, é expresso no art. 190, parágrafo único, do CPC. Os reflexos do publicismo processual sobre a temática impõe tal solução. Trata-se, portanto, de caso de nulidade do negócio, e não de anulabilidade como diz a lei civil (art. 171, II, do CC).

\subsection{Direitos que admitam autocomposição}

As convenções processuais, embora de amplitude mais restrita (não retiram o julgamento do Estado-juiz), são firmadas à luz de princípios comuns à arbitragem (com as partes definindo o modo de ser do processo). Por isso, de modo semelhante ao já previsto no art. 1. ${ }^{\circ}$ da Lei n. ${ }^{\circ}$ 9.307/1996 (Lei de Arbitragem), o art. 190 do CPC estabelece duas condições específicas de validade das convenções processuais: o processo deve versar sobre direitos que admitam autocomposição e as partes devem ser capazes.

Para que seja possível a convenção processual, o objeto do processo - isto é, o direito material a ser debatido ou em debate - deve ser, em princípio, autocomponível (renunciável, reconhecível, transacionável). Todavia, a indisponibilidade do direito material não impede, por si só, a celebração de negócio jurídico processual, devendo ser investigado se há autorização legal para convenções materiais e processuais.

A redação do dispositivo é distinta da do art. $1 .^{\circ}$ da Lei 9.307/1996, ampliando o âmbito de incidência do negócio jurídico processual. Pois, embora, ordinariamente, direitos autocomponíveis sejam mesmo os patrimoniais disponíveis (como aponta a Lei de Arbitragem), há direitos indisponíveis autocomponíveis, cujas regras processuais/procedimentais podem ser passíveis de convenção.

É o caso dos direitos difusos/coletivos, que, apesar de objeto indisponível (o interesse público ou coletivo), admitem a autocomposição por meio da celebração de TAC. Ou os direitos trabalhistas, que apesar tidos por indisponíveis, admitem a celebração de convenção de arbitragem (art. 507-A da CLT, com redação pela Lei n. ${ }^{\circ}$ 13.467/2018) e autocomposição. 
A indisponibilidade do direito material, assim, não impede, por si só, a celebração de negócio jurídico processual, sendo mister investigar a possibilidade de autocomposição. Sendo o direito autocomponível (ainda que indisponível), possível a celebração de convenção processual, inclusive pelo Estado ou em relações de consumo (arts. $4 .^{\circ}$ e $6 .^{\circ}$, VI, do CDC).

No tocante às pessoas jurídicas de direito público, conforme pontuamos outrora ${ }^{9}$, parece que o fato determinante para que possam celebrar convenções processuais, inclusive em tema de execução civil ou fiscal ${ }^{10}$, é a existência de autorização legislativa para autocomposição (específica ou genérica). Havendo disposição legal que permita a celebração de acordo pelo ente federado (cada qual conforme sua disciplina normativa própria), automaticamente está também autorizada, nos limites das atribuições de cada autoridade pública que atua no caso, a celebração de convenções processuais.

\subsection{Partes plenamente capazes}

Só podem celebrar convenções processuais partes plenamente capazes, vistas estas como aquelas com capacidade de contratar (art. 851 do CC). A disciplina legal da capacidade de contratação acaba sendo dada pelos arts. $2 .^{\circ}$ a $5 .^{\circ}$ do CC, sendo lícito afirmar que tanto pessoas físicas quanto jurídicas podem celebrar convenções processuais.

Conforme já afirmado anteriormente (item 2.1 supra), por vedação legal específica (art. 190, caput, CPC) - e não do regime geral dos negócios jurídicos em geral -, não será possível às partes incapazes (arts. 3..$^{\circ}$ e $4^{\circ}$ do CC), mesmo que assistidas ou representadas, celebrarem negócio processual.

Embora se reconheça que a questão é bastante controvertida na doutrina ${ }^{11}$, o interesse público recomendou, tanto quanto no art. 1. ${ }^{\circ}$ da Lei n. ${ }^{\circ}$ 9.307/1996 (Lei de Arbitragem), que a situação jurídica do incapaz, inclusive processual, seja preservada conforme as regras legais (e não convencionais), limitando-se, por conseguinte, a autonomia de sua vontade (na verdade exercitável pelo seu representante/assistente).

\footnotetext{
9 GAJARDONI, Fernando da Fonseca; DELLORE, Luiz; ROQUE, Andre Vasconcelos; OLIVEIRA JR., Zulmar Duarte. Teoria Geral do Processo: Comentários ao CPC/2015. $3^{\text {a }}$ ed. São Paulo: Método, 2019, p. 644/645

${ }^{10}$ ANDRADE, Juliana Melazzi. Negócios jurídicos processuais na execução fiscal. In: Negócios processuais - tomo 2 (coordenadores Antonio do Passo Cabral e Pedro Henrique Nogueira). Salvador: Juspodvm, p. 579.

${ }^{11}$ Admitindo a valildade de convenções processuais por incapazes devidamente representados/assistidos, cf. NOGUEIRA, Pedro Henrique. Negócios jurídicos processuais. $2^{\mathrm{a}}$ ed. Salvador: Juspodvm, 2016, p. 236.
} 
Tanto que a lei condiciona a celebração de convenção por partes plenamente capazes, isto é, que não estejam a depender de interposta pessoa para o exercício de seus direitos processuais (capacidade ad processum). Certa ou errada, essa foi uma opção política do legislador, bem notada pelo Enunciado n. 38 da ENFAM ("Somente partes absolutamente capazes podem celebrar convenção pré-processual atípica”).

Qualquer intenção de admitir que incapazes possam celebrar, por assistentes ou representantes, negócios jurídicos processuais (ainda que vantajosos a eles), implica, em nosso sentir, condenável prática de ver a lei como ela deveria ser, e não como ela é. A adoção da expressão "plenamente capazes" no art. 190 do CPC deve ter algum significado e, como não há palavras inúteis na lei, a única leitura possível da disposição que encontramos é a no sentido de não ser admitida convenção processual por quem não tenha plena capacidade de disposição de seus direitos.

O argumento de que a palavra "plenamente" reforçaria a necessidade de preservação da autonomia da vontade dos convencionantes é frágil, pois tal valor já está devidamente protegido pelo art. 190, parágrafo único, do CPC, ao permitir que o juiz, com base no regime geral dos negócios jurídicos, deixe de aplicar a convenção nos casos de nulidade/anulabilidade, inserção abusiva em contrato de adesão ou de a parte contratante ser manifestamente vulnerável (algo bastante para a tutela da liberdade de contratar).

Evidentemente, celebrada convenção processual por incapaz representado/assistido - ao menos a pré-processual (v.g., regra estabelecendo que o incapaz ficará isento do reembolso das custas ao adversário em caso de sucumbimento) - poderá a nulidade da convenção deixar de ser declarada pelo juiz, por conta da inexistência de prejuízo (arts. 276 e ss. do CPC) ${ }^{12}$. Mas aí o critério adotado para reconhecer os efeitos da convenção não é propriamente o da sua adequação à norma (a convenção continua sendo viciada), mas sim o da inexistência de prejuízo.

Não se tratando de incapazes, inexiste impedimento para que os representantes das pessoas dotadas de personalidade judiciária (condomínio, massa falida, espólio etc.), desde que com autorização assemblear ou judicial, celebrem negócios jurídicos processuais. Este,

\footnotetext{
${ }^{12}$ Em sentido parcialmente semelhante, ver ARRUDA ALVIM, Manual de Direito Processual Civil. $19^{\mathrm{a}}$ ed. São Paulo; RT, 2020, p. 625.
} 
inclusive, é o teor do enunciado 114 das Jornadas de Processo Civil do Conselho da Justiça Federal: "Os entes despersonalizados podem celebrar negócios jurídicos processuais".

\section{Convenções processuais atípicas na execução civil}

Os principais exemplos de convenções processuais atípicas (art. 190 do CPC) advêm de negócios celebrados para operar efeitos no processo de conhecimento. Fala-se na admissão de convenções para ampliar prazos de contestação e recursos; para vedar denunciação à lide; para renunciar antecipadamente ao recurso de apelação contra a sentença; para partilhar as eventuais verbas de sucumbência; entre tantos outros.

Há, entretanto, um campo enorme para a celebração de convenções em tema de execução civil (cumprimento de sentença e execução de título extrajudicial). Ainda que se reconheça no exercício da jurisdição executiva enorme preponderância da natureza pública/estatal do processo - até porque são praticados atos coativos e de invasão patrimonial pelo Estado/Juiz, ordinariamente vedados ao particular -, absolutamente nada impede que as partes, observadas as 06 (seis) condições retro expostas e o monopólio do uso da força pelo Estado, moldem também o processo e o procedimento executivos às suas vontades ou às especificidades da causa.

Até porque, convenha-se, também a execução se rege pelo princípio da disponibilidade. $\mathrm{O}$ art. 775 do $\mathrm{CPC}$ estabelece que o exequente tem o direito de desistir de toda a execução ou de apenas alguma medida executiva. Se pode, no curso da execução ou do cumprimento de sentença, renunciar/desistir de determinadas faculdades ou direitos que lhe são assegurados em lei, também pode fazê-lo por convenção processual (antes ou no curso da execução), não só para conformar a tutela estatal executiva à vontade das partes (credor/devedor), mas também para permitir: a) maior humanização da execução, com a redução do poder do Estado sobre a situação jurídica do devedor; e b) maior efetividade da execução, com a redução do espectro público de proteção jurídica à pessoa do devedor, ou com remodelação do procedimento executivo a bem de eliminar óbices que impeçam o seu célere andamento.

Por isso, parece não haver problemas para que sejam admitidas as convenções processuais a seguir exemplificativamente indicadas (inclusive em desfavor do devedor), 
todas celebradas com o fim de implementar mudanças no processo/procedimento do cumprimento de sentença ou da execução de título extrajudicial.

a) pacto de não executar (pacto de non exequendo), que diversamente da renúncia ao direito em que se funda a execução ou do pacto de non petendo ${ }^{13}$, veda ao credor dar início à execução de título extrajudicial (por prazo certo ou indeterminadamente), não estando proibido, todavia, de exercer medidas extrajudiciais a bem do recebimento do crédito (v.g. protesto do título, inserção do nome do devedor no rol de maus pagadores, etc. $)^{14}$, ou mesmo de reclamar o pagamento pela via do processo de conhecimento;

b) calendarização da execução ou do cumprimento de sentença (algo bastante caro ao processo coletivo estrutural), a fim de que, exemplificativamente, seja avençado o cumprimento parcial e progressivo da obrigação, inclusive com estabelecimento de órgão (judicial ou extrajudicial) de acompanhamento de implementação/cumprimento das ações avençadas.

c) convenção dos credores na recuperação judicial ou falência, com arrimo no art. 35 da Lei 11.101/2015, para: i) pactuar a forma de manifestação da vontade dos credores a respeito do plano, estabelecendo o voto escrito e não em assembleia, desde que seja possível ao administrador judicial conferir a autenticidade do voto; ii) ajustar nova modalidade de comunicação dos atos processuais, desde que sejam seguras, como, por exemplo, a publicação no endereço eletrônico do administrador judicial, eliminando-se as custosas publicações de editais; iii) estabelecer que as impugnações sejam processadas extrajudicialmente pelo administrador judicial e que a impugnação integralmente processada seja protocolada em juízo para decisão, poupando-se o cartório de repetidos atos de comunicação; iv) ajustar sessões de mediação, de modo a permitir que os interessados apresentem suas necessidades e que o devedor proponha um plano para a superação da crise que atenda aos diferentes grupos de credores; e v) fixar calendário processual, com o objetivo de trazer previsibilidade, celeridade e economia ao procedimento, ficando os credores

\footnotetext{
13 SILVA, Paula Costa e. Pactum de non petendo: exclusão convencional do direito de ação e exclusão convencional da pretensão material. In: CABRAL, Antonio do Passo; NOGUEIRA, Pedro Henrique Pedrosa (Coord.). Negócios processuais. $3^{\mathrm{a}}$ ed. Salvador: JusPodivm, 2017, p. 451 e ss.

${ }^{14}$ CABRAL, Antonio do Passo; DIDIER JR., Fredie. Negócios jurídicos processuais atípicos e execução. Revista do Ministério Público do Rio de Janeiro, n. 67, jan-mar/2018, p. 146.
} 
cientes desde o início das datas em que os atos processuais serão praticados, incluindo a apresentação do plano e as datas de realização da assembleia-geral de credores ${ }^{15}$.

d) pacto para dispensa de caução para fins de cumprimento provisório de sentença (art. 520, V, do CPC), admitindo que atos de expropriação e levantamento de valores em dinheiro possam ser praticados independentemente de prestação de garantia por parte do credor;

e) acordo para vedar o cumprimento provisório de sentença, na forma do art. 520 e ss. do CPC, criando, por assim dizer, um efeito suspensivo convencional dos recursos ordinários e extraordinários interpostos pelas partes (que só poderiam efetivar a decisão após o trânsito em julgado);

f) ampliação de hipóteses de impenhorabilidade de bens pela via negocial, com o devedor/credor avençando, inclusive para fins de preservação do funcionamento da empresa devedora, outras hipóteses, para além do art. 833 do CPC, em que os bens do executado não estariam sujeitos à expropriação judicial (v.g., impedindo a penhora de ativos em conta da empresa, protegendo o capital de giro da executada);

g) convenção processual para dispensa, ampliação ou redução da multa de $10 \%$ pelo não pagamento da condenação por quantia no prazo de 15 dias (art. 523, § $1^{\circ}$, do CPC);

h) acordo para estabelecimento de multa pelo não cumprimento da execução de título extrajudicial de quantia no prazo de 03 (três) dias (art. 829 do CPC) ou outro que as partes avençarem;

i) negócio processual para permitir a aplicação da regra do art. 916, do CPC (parcelamento), também ao cumprimento de sentença de quantia (algo inexplicavelmente vedado pelo $\S 7^{\circ}$ da disposição), permitindo, assim, que no prazo de 15 dias para pagamento do art. 523 do CPC (ou outro que as partes avençarem), possa o executado, depositando 30\% do valor total devido incluindo custas e honorários (ou outro percentual eleito na convenção), pagar o restante em outras 06 parcelas (ou mais, conforme definido na convenção);

j) convenção de remodelação do art. 916 do CPC, admitindo, por exemplo, que nos casos em que não efetuado o pagamento parcelado, seja possível a oposição de embargos do devedor (afastada, assim, a vedação do art. 916, § 6º do CPC);

\footnotetext{
${ }^{15}$ FURTADO, Paulo. O negócio jurídico processual na recuperação judicial. Migalhas. São Paulo. Disponível em: https://www.migalhas.com.br/coluna/insolvencia-em-foco/284720/o-negocio-juridico-processual-narecuperacao-judicial. Publicado em: 31.07.2018.
} 
k) convenção para condicionar o ajuizamento da execução de título extrajudicial à notificação extrajudicial ou protesto prévios, ou mesmo a uma tentativa de conciliação extrajudicial prévia, o que não é inconstitucional, considerando que o condicionamento ao acesso ao Poder Judiciário partiu de ato das próprias partes (como na arbitragem), e não da lei ou outro normativo de terceiro (como é inadmitido pelo art. $5^{\circ}, \mathrm{XXXV}$, da $\mathrm{CF}$ );

1) convenção para inadmitir averbação da execução (art. 918 do CPC), evitando embaraços extrajudiciais à realização de negócios pelo executado (inclusive estabelecendo alguma sanção ao devedor que, alienando o bem ao terceiro de boa-fé, quebre a regra da patrimonialidade);

m) negócio processual para estabelecer ordem convencional para penhora dos bens do devedor em caso de execução forçada (afastando a ordem legal do art. 835 do CPC), exemplificativamente, vedando a penhora preferencial de dinheiro via SISBACEN ${ }^{16}$;

n) convenção processual para redução de prazo de desocupação (de 60 para 05 dias), em casos de inadimplemento do devedor fiduciário e consolidação da propriedade em nome do fiduciante, afastando-se, assim, a incidência do art. 30 da Lei 9.514/97 (TJSP, Agravo de Instrumento 2269263-77.2018, 6a Câmara Direito Privado, Rel. Juiz Rodolfo Pellizari, j. 07.01.2019);

o) convenção de alienação da coisa penhorada, em $2^{\mathrm{a}}$ praça, em preço inferior $40 \%$ do preço da avaliação, afastando a incidência do art. $880, \S 1^{\circ}$, do CPC (que trata do preço vil), por evidente com controle judicial dos requisitos expostos no item 2 supra, especialmente da autonomia da vontade das partes. Pontue-se, contudo, que há precedente do TJSP reconhecendo a invalidade de tal convenção, sob o fundamento de que se trata de regra de "ordem pública” (TJSP, Agravo de Instrumento n. 2191919-20.2018, $15^{\text {a Câmara }}$ de Direito Privado, Rel. Juiz José Wagner Peixoto, j. 04.10.2018);

p) convenção processual para só permitir a alienação particular ou em hasta pública da coisa, mediante o pagamento do preço da avaliação, excepcionando-se a regra do art. 880 do CPC;

q) convenção em acordo de divórcio (judicial ou extrajudicial), com fixação de pensão alimentícia em favor de um dos cônjuges capaz, para fim de vedar, desde logo,

16 TEMER, Sofia; ANDRADE, Juliana Melazzi. Convenções processuais na execução: modificação consensual das regras relativa à penhora, avaliação e expropriação de bens. In: Coletânea mulheres no processo civil brasileiro - negócios processuais (Coordenadores Ana Marcato et al). Salvador: Juspodvm, 2018, p. 558. 
execução de alimentos pelo rito da prisão (arts. 528, $\S \S 3^{\circ}$ e $7^{\circ}$ e 911 do CPC), devendo os valores alimentares serem cobrados, exclusivamente, pelo rito da execução por quantia (arts. $528, \S 8^{\circ}$, e 919 do CPC).

r) negócio processual para permitir a alienação antecipada do bem penhorado, para além das hipóteses bastante restritas do art. 852 do CPC;

Por outro lado, há outras tantas convenções processuais imagináveis em sede executiva, que não seriam válidas/eficazes por transbordarem os 06 (seis) limites já estabelecidos dos arts. 104 e 171 do CC e art. 190 do CPC (item 2 supra), ou o monopólio do uso da força pelo Estado (execução forçada).

Assim, seriam inadmissíveis convenções processuais antecedentes ou incidentais:

a) que admitam a prisão civil do devedor fora das hipóteses constitucionais (devedor de alimentos - art. $5^{\circ}$, LXVII, da CF), vez que o conteúdo da convenção teria objeto ilícito, já que violadora do regramento da patrimonialidade da execução e da vedação constitucional da prisão civil;

b) que vedem, em acordo extrajudicial para fixação de pensão alimentícia em favor de incapaz - ainda que devidamente representado ou assistido -, execução dos alimentos inadimplidos pelo rito da prisão (art. 911, parágrafo, CPC), pois que a avença fora celebrada com parte que não é "plenamente capaz”, como impõe o art. 190, caput, do CPC;

c) que impliquem renúncia prévia, pelo executado, do exercício do direito de defesa via embargos (art. 914 do CPC) ou impugnação ao cumprimento de sentença (art. 525 do $\mathrm{CPC}$ ), considerando que o pacto tem objeto ilícito na medida em que viola o contraditório (conteúdo mínimo do processo constitucional);

d) que autorizem a penhorabilidade de todo o patrimônio do devedor, privando-o, assim, da própria subsistência em caso de não cumprimento da obrigação, pois a avença, desta forma, teria objeto ilícito por violar os princípios da dignidade da pessoa humana (art. $1^{\circ}$, III, da CF); por não preservar patrimônio/renda mínima para que o devedor se mantenha, nos mesmos moldes do considerado em tema de doação (art. 548 do CC);

e) que atribuam eficácia de título judicial (art. 515 do CPC) a documento ou título extrajudicial, expediente que, por via transversa, afeta o contraditório, pois priva o devedor 
do exercício adequado do direito de defesa (limitação considerável das matérias arguíveis em impugnação, na forma do art. $525, \S 1^{\circ}$, do CPC), tendo, portanto, objeto ilícito ${ }^{17}$;

f) inseridas, abusivamente, em contrato de adesão (art. 54 do CDC e arts. 423/424 do CC), vista a abusividade como sendo aquela derivada da ausência ou impossibilidade de manifestação de vontade livre do aderente, vez que haveria, neste caso, ofensa à condição da autonomia da vontade;

g) que afastem o controle judicial ou reduzam o prazo de fiscalização judicial da recuperação judicial, considerando que há propriamente um dever de fiscalização do juiz, na forma art. 61 da Lei 11.101/2005, o qual não é de titularidade dos credores ou do recuperando e, como tal, não pode ser objeto de convenção (TJSP, Agravo de Instrumento n. 220576082.2018, 2ª Câmara de Direito Empresarial, Rel. Sérgio Shimura, j. 04.02.2019)

h) que em acordo celebrado pelas partes na fase de cumprimento de sentença, determina, em caso de descumprimento da avença, a avaliação dos bens dados em garantia de pagamento por perito do Tribunal e sem ônus ao exequente/executado, vez que, nesta convenção processual, estaria se deliberando sobre dever estranho às partes, faltando-lhes capacidade (TJSP, Agravo de Instrumento n. 2233954-58.2019, 25 Câmara de Direito Privado, Rel. Carmen Lúcia da Silva, j. 24.03.2020);

Mas há convenções processuais na execução absolutamente complexas, de cabimento bastante duvidoso à luz do direito brasileiro, merecedoras de mais aprofundada reflexão e debate, entre elas:

a) convenções sobre extrajudicialização (total ou parcial) da execução;

b) convenções para incidência de medidas executivas atípicas em caso de inadimplemento;

c) convenções de penhora da remuneração do devedor; e

d) convenções sobre a penhorabilidade do bem de família legal.

As notas que a seguir se apresentam objetivam trazer alguns subsídios mais objetivos para a análise do tema, buscando respostas para a admissão/inadmissão dos referidos

${ }^{17}$ GAJARDONI, Fernando da Fonseca; DELLORE, Luiz; ROQUE, Andre Vasconcelos; OLIVEIRA JR., Zulmar Duarte. Teoria Geral do Processo: Comentários ao CPC/2015. $3^{\mathrm{a}}$ ed. São Paulo: Método, 2019, p. 699. 
negócios jurídicos processuais com foco na análise o caso concreto e dos próprios requisitos (gerais e específicos) estabelecidos no item 2 supra.

De modo que, na busca de tais respostas, serão voluntariamente abandonados conceitos jurídicos incertos e indeterminados que, usualmente, são invocados nos debates sobre convenções processuais na execução civil - cuja definição e eleição das hipóteses é algo bastante controvertido no Brasil e no mundo" ${ }^{18}$ - como os "de espaços ou regras de ordem pública" e "cogência das normas sobre execução".

Só o tempo e a orientação dos Tribunais poderão guiar, com a segurança necessária, os operadores jurídicos no sentido do cabimento (ou não) das referidas convenções. No estado atual da arte do direito processual civil brasileiro, não se vê boas perspectivas, do ponto de vista da segurança jurídica, para que elas sejam celebradas, até porque tudo é ainda absolutamente incerto nesta temática.

\subsection{Convenção processual de extrajudicialização (total ou parcial) da execução civil}

Tramita no Congresso Nacional brasileiro o projeto de lei (PLS) n. 6204/2020, que dispõe sobre a desjudicialização da execução civil de título executivo judicial e extrajudicial.

Ressalvados os casos de partes incapazes, presos ou internados, pessoas jurídicas de direito público, massa falida e o insolvente civil, pelo projeto as execuções civis poderiam se dar de modo extrajudicial, funcionando os tabeliães de protestos como agentes de execução, com atribuições para: I - examinar o requerimento e os requisitos do título executivo, bem como eventual ocorrência de prescrição e decadência; II - consultar a base de dados mínima obrigatória, nos termos do art. 29, para localização do devedor e de seu patrimônio; III - efetuar a citação do executado para pagamento do título, com os acréscimos legais; IV - efetuar a penhora e a avaliação dos bens; V - realizar atos de expropriação; VI - realizar o pagamento ao exequente; VII - extinguir a execução; VIII - suspender a execução diante da ausência de bens suficientes para a satisfação do crédito; IX - consultar o juízo competente para sanar dúvida relevante; $X$ - encaminhar ao juízo competente as dúvidas suscitadas pelas partes ou terceiros em casos de decisões não reconsideradas (art. $4^{\circ}$ do PLS 6204/2020).

\footnotetext{
${ }^{18}$ SILVA, João Paulo Hecker da. Convençães processuais na execução e desjudicialização da atividade satisfativa. In: Direito Bancário (coordenadores Marcio Calil de Assumpção e Gabirel José de Orleans e Bragança. São Paulo: Quartier Latin, 2018, p. 167.
} 
Em sendo aprovado o projeto, passaríamos a ter, para além da execução judicializada, também a possibilidade de a parte buscar a satisfação do crédito representado por título executivo (judicial ou extrajudicial) perante as serventias extrajudiciais (tabelionato de protestos), com atribuição não só para recepção e documentação da execução, mas também para a prática de atos de execução forçada como a apreensão, constrição e expropriação de bens do devedor.

Evidentemente o PLS 6204/2020 ainda será objeto de intensa sabatina junto ao Poder Legislativo brasileiro, o qual considerará todas as vantagens (e desvantagens) da adoção da prática, à luz da realidade brasileira (que é regionalmente desigual), da capacidade de os tabelionatos funcionarem estruturalmente com agentes de execução (sem cometer abusos) e da experiência dos países que já admitem a execução extrajudicial.

Neste instante calha aferir se seria possível, já à luz do modelo vigente, que as partes, através das convenções (pré) processuais do art. 190 do CPC, pactuem a extrajudicialização (total ou parcial) da execução.

Como é de sabença geral, ressalvadas algumas raras hipóteses em que é permitida a autotutela, o monopólio do uso da força é do Estado, que através de seus órgãos afirmam e realizam, se necessário através de atos coativos e de sub-rogação, a vontade da lei (espelhada no título executivo).

A corroborar tal afirmação, basta ver que mesmo em sede de arbitragem - onde a autonomia de vontade das partes é ainda maior do que a dos próprios negócios processuais (pois alijam o Estado da própria participação na decisão do conflito) -, não se cogita admitir que os árbitros ou as cortes arbitrais possam impor, coativamente, seus pronunciamentos (execução forçada), pois não dotados dos atributos jurisdicionais da coertio e da executio (exclusivos da jurisdição estatal). Ainda que haja diversos mecanismos de coerção não processuais que acabam tornando extremamente penoso o descumprimento, pelas partes, da sentença arbitral, é evidente que estes mecanismos de coerção não são suficientes, de modo que a intervenção estatal pode ser necessária para, através do Estado/Juiz, se impor forçadamente o cumprimento da sentença arbitral (art. 515, VII, do CPC) ${ }^{19}$.

${ }^{19}$ CARMONA, Carlos Alberto. Arbitragem e processo: um comentário à lei no 9.307/96. $3^{\text {a }}$ ed. São Paulo: Atlas, 2009, 381. 
Também como é de sabença geral, é na execução civil que o Estado/Juiz, de ordinário transforma a declaração do direito (dever ser) em realidade prática (ser), realizando a transformação (obrigações de fazer), o desapossamento (obrigações de entrega) ou a expropriação (obrigações de pagar quantia), através dos nominados atos de execução forçada, como a busca e apreensão, a imissão na posse, a penhora e a expropriação de bens (adjudicação e alienação).

Para hipóteses bastante específicas, a legislação brasileira até prevê a prática de atos típicos de execução extrajudicialmente, com o Estado/Juiz participando do controle da legalidade/oportunidade da execução extrajudicial, apenas, se provocado pelas partes (especialmente pelo devedor executado). Os arts. $2^{\circ}$ e $3^{\circ}$, § $1^{\circ}$, do DL 911/69, autorizam o credor fiduciário, independentemente de prévia autorização judicial e após o ato inicial estatal/judicial de apreensão do bem, possa, a consolidar em seu nome a propriedade móvel ou aliená-lo extrajudicialmente (mesmo antes da sentença da ação de busca e apreensão), inclusive transferindo-o a quem lhe aprouver. Do mesmo modo, os DL 70/66 (execução hipotecária) e Lei 9.514/97, autorizam o agente financeiro (hipotecário ou fiduciário) a consolidar em seu nome a propriedade do bem imóvel cujo financiamento foi inadimplido, inclusive podendo vende-lo extrajudicialmente (sem nenhuma autorização ou participação do Estado/Juiz) para pagamento (total ou parcial) da dívida do financiado inadimplente. Nestes casos, observe-se que a possibilidade de alienação extrajudicial do bem ou da completa execução extrajudicial da obrigação deriva de lei em sentido estrito.

Não há na execução civil, contudo, apenas atos de execução forçada. Para além de existir atividade satisfativa não forçada (como nos casos das ações declaratórias/constitutivas ou que reconheçam obrigação de declarar vontade, que, de ordinário, não dependem de atos de força para serem efetivadas), diversas atividades do juiz, mesmo na execução forçada, são destinadas à documentação, integração ao contraditório e instrução da execução (e não propriamente na prática de atos de força). De modo que, à luz do art. 190 do CPC e do poder de autorregramento das partes, não parece ser possível afastar, prima facie, a possibilidade de as partes convencionarem sobre tais aspectos da execução forçada, ou mesmo de extrajudicializar (desjudicializar) casos em que a execução não é forçada. 
Por conseguinte, e sempre com a ressalva da necessária observância das condicionantes gerais e específicas dos negócios processuais (item 2 supra), possível convenções processuais para extrajudicializar (ou desjudicializar), total ou parcialmente, a execução civil, permitindo ao próprio credor, sem a intervenção do Estado, a prática diretamente de atos executivos, com inversão da iniciativa do contraditório para que o devedor eventualmente prejudicado pela desjudicialização, acione o Poder Judiciário para o reconhecimento da invalidade do negócio processual e controle dos atos extrajudicialmente praticados pelo credor.

Assim, não se vê óbice para a celebração de convenção para extrajudicializar a intimação ou citação do devedor no cumprimento de sentença ou execução de título extrajudicial, com as partes pactuando um procedimento prévio de integração do devedor à execução a ser judicializada (email, notificação extrajudicial, etc), dispensando o Estado/Juiz do cumprimento do arts. 246, 513, § $2^{\circ}$ ou 829 , do CPC, já partindo a decisão inaugural da execução judicial, em vista do decurso do prazo extrajudicial para pagamento, para os atos de execução forçada (penhora, apreensão, etc.). Trata-se de ato de documentação/integração do credor/devedor à execução, que por isso pode ser extrajudicializado. Por evidente, só será considerado válido o procedimento extrajudicial de integração do devedor à execução se houver segurança suficiente na confirmação do recebimento da comunicação, pois, do contrário, o ato será considerado inválido pelo Poder Judiciário tão logo seja chamado a iniciar o procedimento já na fase expropriatória.

Possível, também, convenção processual para realização de avaliação extrajudicial de bens penhorados por terceiro (com ou sem caráter vinculativo ao juiz), restando dispensada, assim a avaliação judicial (por oficial de justiça ou perito), nos termos do art. 870 e parágrafo único, CPC, pois tem-se, aqui, ato de instrução da execução e que, como tal, pode ser extrajudicializado.

Por fim, embora se trate de questão mais polêmica, parece ser admissível convenção para que as partes, em situações semelhantes à da Lei 9.514/97 ou DL 911/69, avencem a consolidação da propriedade (móvel ou imóvel) de bem alienado em casos de inadimplemento, sem a necessidade de acionamento do Poder Judiciário para a 
operacionalização da adjudicação do bem ao credor $^{20}$. A extrajudicialização por aqui pode ser admitida em vista de não haver necessidade de atos de força pelo particular (execução não forçada), pois a transferência da propriedade móvel ou imóvel (do devedor inadimplente para o credor) se dará no registro da propriedade do bem, nos termos da convenção, podendo o devedor prejudicado acionar o Judiciário, a qualquer tempo, para arguir ilegalidades no procedimento extrajudicial ( $v . g$., como nos caos de falta de notificação para purgação da mora ou abusividade nos valores exigidos e que levaram à perda do bem).

Por outro lado, à míngua de previsão legal específica - como é a buscada pelo citado PLS 6204/2020 -, são vedadas convenções processuais para substituir o Estado/Juiz na prática dos já referidos atos de apreensão física típicos de execução forçada, como a busca e apreensão, a imissão na posse, a penhora e a expropriação extrajudicial dos bens de propriedade do devedor.

O monopólio estatal da força impede que o credor, sem a intervenção do Judiciário, possa levar adiante tais medidas, de modo que não será possível - salvo nas ressalvas legais expressas -, a integral extrajudicialização da execução civil por negócio jurídico processual (mesmo que esteja o devedor acordo), pois que de objeto ilícito e atinente a poder de terceiro (uso privativo da força pelo Estado).

Poderia se cogitar ser admissível convenção estabelecendo, após a penhora (realizada judicialmente) e a avaliação (que pode ser pactuada para realização extrajudicial), a alienação extrajudicial do bem via próprio credor ou terceiro indicado na convenção. Tal possibilidade, contudo, não deriva, propriamente, de negócio jurídico processual atípico (que não é admitido à luz das premissas já estabelecidas), mas sim do regramento já existente dos arts. 879 e 880, do CPC, que permitem a alienação particular do bem penhorado (que de todo modo ocorre sob a fiscalização do Estado/Juiz).

Dentro desta mesma perspectiva, não parece possível que as partes pactuem excluir o Estado/Juiz do controle do regramento, validade e eficácia desta especial hipótese de alienação do bem (que é judicial, pois realizada mediante autorização/controle do Estado/Juiz). A vedação à autotutela impede que as partes possam afastar a incidência da atuação estatal na forma dos artigos 879 e 880 do CPC (embora não esteja impedido o

\footnotetext{
${ }^{20}$ SILVA, João Paulo Hecker da. Convençães processuais na execução e desjudicialização da atividade satisfativa. In: Direito Bancário (coordenadores Marcio Calil de Assumpção e Gabirel José de Orleans e Bragança. São Paulo: Quartier Latin, 2018, p. 182/183.
} 
regramento acessório para realização da alienação particular, como o estabelecimento por convenção de preço mínimo da coisa).

\subsection{Convenções (pré) processuais para incidência de medidas atípicas de indução e} coerção em casos de inadimplemento

Estabelece o art. 139, VI, do CPC, que compete ao juiz, na qualidade de presidente do processo, determinar todas as medidas indutivas, coercitivas, mandamentais ou subrogatórias necessárias para assegurar o cumprimento de ordem judicial, inclusive nas ações que tenham por objeto prestação pecuniária.

Trata-se de positivação da dever de efetivação no processo civil brasileiro, dentro da ótica de que, frente ao monopólio da força pelo Estado, a parte não conta com ninguém mais, a não ser o próprio Estado/Juiz, para fazer a obrigação representada em título judicial ou extrajudicial valer ${ }^{21}$.

Por isso, a partir da disposição, sustenta-se a admissão, no sistema processual vigente, do modelo da atipicidade das medidas executivas no cumprimento de sentença e no processo de execução de pagar quantia, pelo que seria lícito ao juízo, no curso da execução forçada, impor medida executiva de qualquer natureza a bem de compelir o devedor a cumprir a obrigação ou revelar seu patrimônio, ainda que à míngua de previsão legal específica. O enunciado n. 48 das Jornadas da ENFAM sobre o CPC/2015 é sintomático:

"O art. 139, IV, do CPC/2015 traduz um poder geral de efetivação, permitindo a aplicação de medidas atípicas para garantir o cumprimento de qualquer ordem judicial, inclusive no âmbito do cumprimento de sentença e no processo de execução baseado em títulos extrajudiciais".

Exemplificativamente, e ao menos em tese, superados os expedientes tradicionais de adimplemento (penhora de bens, busca a apreensão etc.), não efetuado o pagamento de dívida oriunda de multas de trânsito, ou mesmo não indicado o paradeiro da coisa nas ações de busca e apreensão de bem alienado fiduciariamente (DL n. ${ }^{\circ}$ 911/1969), seria lícito o estabelecimento da medida coercitiva/indutiva de suspensão do direito a conduzir veículo automotor (inclusive em sede de execução fiscal) até o pagamento do débito ou a revelação

\footnotetext{
${ }^{21}$ GAJARDONI, Fernando da Fonseca. A revolução silenciosa da execução por quantia. Jota. Brasília-DF. Disponível em: www.jota.info/opiniao-e-analise/artigos/a-revolucao-silenciosa-da-execucao-por-quantia24082015. Publicado em: 24.08.2015.
} 
do paradeiro da coisa (inclusive com apreensão da $\mathrm{CNH}$ do devedor); não efetuado pagamento de verbas salariais devidas a funcionários da empresa, possível o estabelecimento de vedação à contratação de novos funcionários até que seja saldada a dívida; não efetuado o pagamento de financiamento bancário na forma e no prazo avençados, possível, até que se tenha a quitação, que se obstem novos financiamentos na mesma instituição, ou mesmo a participação do devedor pessoa jurídica em licitações (como de ordinário já acontece com pessoas jurídicas em débito tributário com o Poder Público; não cumprida a obrigação de pagar quantia do devedor com agência de viagem internacional, razoável admitir a apreensão do seu passaporte até que venha ser saldada a dívida ${ }^{22}$.

A capacidade de a interpretação potencializada do dispositivo trazer resultados positivos para a causa da efetividade da execução é igualmente proporcional à possibilidade de que sejam excedidos os limites do razoável, com a prática de verdadeiros abusos judiciais contra inadimplentes, inclusive violando-se direitos fundamentais.

Por isso - a prevalecer a interpretação potencializada do art. 139, IV, do CPC -, o emprego de tais medidas coercitivas/indutivas, especialmente nas obrigações de pagar, encontrará limite certo em algumas regras que já estão sendo adequadamente tratadas por parcela importante da doutrina ${ }^{23}$ e da jurisprudência (STJ, RHC 97.876-SP, Relator Ministro Luis Felipe Salomão, j. 05.06.2018; RHC 99.606, 3ª turma, Rel. Min. Nancy Andrighi, j. 13/11/2018; HC 478.963-RS, Rel. Min. Francisco Falcão, $2^{\text {a }}$ Turma, j. 20/4/2019), sempre com o escopo de assegurar que a incidência delas não viole garantias constitucionais.

No curso da execução judicial forçada, as medidas atípicas de indução/coerção estariam sujeitas ao rigoroso controle do Estado/Juiz, que inclusive avaliaria o cabimento das eleitas pelo exequente, à luz da proporcionalidade e da excepcionalidade da medida. A questão toda é saber se poderiam as partes, por convenção processual (especialmente pré-

\footnotetext{
${ }^{22}$ Para outros exemplos, cf. OLIVEIRA NETO, Olavo. O poder geral de coerção. São Paulo: RT, 2019, p. $266 / 312$.

${ }^{23}$ RODOVALHO, Thiago. O necessário diálogo entre doutrina e jurisprudência na concretização da atipicidade dos meios executivos. Jota. Brasília. Disponível em: www.jota.info/opiniao-e-analise/artigos/o-necessariodialogo-entre-doutrina-e-jurisprudencia-na-concretizacao-da-atipicidade-dos-meios-executivos-21092016.

Publicado em: 21.09.2016; MINAMI, Marcos Youji. Da vedação ao non factibile: uma introdução às medidas executivas atípicas. Salvador: Juspodvm, 2016, p. 323; e BORGES, Marcus Vinicius Motter. Medidas coercitivas atípicas nas execuções pecuniárias. São Paulo: RT, 2019, p. 215/366.
} 
processual), estabelecer a admissão ou vedação de tais medidas atípicas nas hipóteses de inadimplemento da obrigação.

Não temos dúvida alguma em admitir que as partes possam limitar, por convenção processual, o poder de efetivação do juiz à luz do art. 139, IV, do CPC. Tais medidas são deferidas, sempre, em favor do exequente (tendo ele como destinatário), que pode, por isso, através de convenção processual, restringir o alcance das medidas executivas (típicas e atípicas) que poderia o Estado/Juiz adotar em seu favor, como se de renúncia antecipada se tratasse, inclusive à luz do já referido art. 775 do CPC (que permite ao credor desistir de toda execução ou de alguma medida executiva).

Desde que observadas as condicionantes do item 2 supra, plenamente possível convenção processual para afastar qualquer medida executiva que fosse aplicada a bem da satisfação da obrigação, inclusive as que derivam da própria lei (típicas). Cabe negócio préprocessual ou processual para: a) afastar a incidência da multa do art. $523, \S 1^{\circ}$, do CPC, nos cumprimentos de sentença por quantia (caso em que a satisfação do crédito será buscada sem a medida coercitiva derivada da lei); b) impedir a penhora de determinados bens para além do rol dos artigos 833 e 834 do CPC e Lei 8.009/90; c) impedir o juiz de adotar medidas executivas típicas como a de apontamento do nome do devedor no rol de maus pagadores (art. 782, § $3^{\circ}$, do CPC), ou mesmo de vedar o protesto judicial da sentença, pese os termos do art. 517 do CPC; e d) porque não, vedar a concessão de medidas atípicas como suspensão de $\mathrm{CNH}$, apreensão de passaporte, bloqueio de cartão de crédito, etc.

Também entendemos possível - embora não se negue que neste quadrante a questão seja mais complexa do ponto de vista da necessidade de rigoroso controle judicial da medida eleita (art. 190, parágrafo único, do CPC) - que as partes possam convencionar medidas atípicas (que se tornariam convencionalmente típicas), na forma do arts. 139, IV, e 190, do CPC, a serem empregadas em caso de inadimplemento, a fim de compelir o devedor a revelar onde estão os bens penhoráveis ou cumprir a obrigação. Afinal, o estabelecimento de medidas coercitivas e inibitórias, extra e pré-processualmente para os casos de inadimplemento da obrigação, pode servir de poderoso instrumento de pressão em favor da satisfação dela, especialmente quando se esteja diante de situação em que o próprio devedor - dentro das premissas/condicionantes estabelecidas no item 2 supra, e muitas vezes para obter uma vantagem na negociação do ponto de vista do direito material (redução de juros, 
maior prazo para pagamento do débito, etc.) -, tenha livre e voluntariamente aceitado a sua incidência nas hipóteses em que venha a não cumprir sua obrigação (e até que ela seja cumprida).

Consequentemente, não se vê óbice para que o devedor, por negócio processual (inclusive pré-processual), aceite a incidência automática de consequências executivas outras, para além das expressamente previstas em lei processual (multas, penhora, expropriação de bens), como, por exemplo, a suspensão da sua $\mathrm{CNH}$ caso não haja pagamento pontual do débito e enquanto isso perdurar; ou a indisponibilidade de alguns de seus bens até o pagamento da dívida; etc.

Obviamente a medida atípica eleita ficaria - como todo negócio processual -, sujeita a controle judicial oficioso (art. 190, parágrafo, CPC), inclusive para fins de aferição de eventual nulidade ou vulnerabilidade do devedor quando da pactuação, ou mesmo no tocante à excessividade/onerosidade da medida se, após incidente (no curso da execução), ficar constatado sua ineficiência para compelir o pagamento ou indicação de bens (quando, então, deve deixar de incidir, sob pena de ser converter em pena). Algo fácil de se operacionalizar porque, na maioria das vezes, a incidência destas medidas atípicas vai depender da instrumentalização/aplicação por decisão do juiz (como a suspensão da CNH e indisponibilidade de bens, que dependerão de ordem judicial ao DETRAN ou central de indisponibilidade) que, portanto, durante toda sua incidência tem como fiscalizar se a medida ainda atende aos seus fins.

Mas não se pode negar, em princípio, a possibilidade de celebração da convenção processual tanto para limitar os poderes de efetivação do juiz quanto, também, para avençar a incidência automática de medidas atípicas enquanto perdurar o inadimplemento do devedor $^{24}$ (VOGT, 2019, p. 182).

\subsection{Convenção processual de penhorabilidade dos rendimentos do devedor}

Conforme locução do art. 833, VI, do CPC, são impenhoráveis os vencimentos, os subsídios, os soldos, os salários, as remunerações, os proventos de aposentadoria, as pensões, os pecúlios e os montepios, bem como as quantias recebidas por liberalidade de terceiro e

\footnotetext{
${ }^{24}$ VOGT, Fernanda Costa. A tomada do procedimento pela vontade: as convenções processuais e o princípio da atipicidade na execução civil. Civil Procedure Review, v. 10, n.3, set-dez/2019, p. 182.
} 
destinadas ao sustento do devedor e de sua família, os ganhos de trabalhador autônomo e os honorários de profissional liberal.

A própria lei, contudo, ressalva a impenhorabilidade, para admitir que em ao menos 02 (dois) casos seja possível a penhora sobre os rendimentos do devedor (art. $833, \S 2^{\circ}$, do CPC): a) para os créditos alimentares (pouco importa qual seja o valor dos rendimentos do devedor); e b) para os créditos de qualquer natureza, no que os rendimentos do devedor excederem a importância de 50 (cinquenta) salários-mínimos.

Em vista das bastante restritas hipóteses de penhorabilidade dos rendimentos do devedor - o que revela, aliás, a completa e total falta de noção do legislador sobre a real condição econômica do trabalhador brasileiro (sendo raríssimos os casos de pessoas com ganhos para além de $50 \mathrm{sm}$ ) -, o STJ, em condenável iniciativa do ponto de vista das atribuições do Poder Judiciário (pois a decisão vai de encontro ao limite semântico do art. 833, IV, do CPC), tem admitido a penhora dos rendimentos do devedor que aufira menos dos que 50 salários, pouco importando a natureza do crédito, desde que seja possível aferir no processo que, mesmo com a supressão de parcela do rendimento, sobeje quantia suficiente para o devedor se manter.

Prevaleceu na Corte do Superior Tribunal de Justiça o entendimento de que a regra geral de impenhorabilidade de vencimentos pode ser excepcionada a fim de garantir a efetividade da tutela jurisdicional do crédito, desde que observado percentual suficiente de assegurar a dignidade do devedor e de sua família (EREsp 1.582.475/MG, Rel. Min. Benedito Gonçalves, j. 15.10.2018).

Consta do voto do relator, entre outros trechos, ideias como as de que: a) a interpretação dos preceitos legais deve ser feita a partir da Constituição da República, que veda a supressão injustificada de qualquer direito fundamental; b) a impenhorabilidade de salários, vencimentos, proventos etc. tem por fundamento a proteção à dignidade do devedor, com a manutenção do mínimo existencial e de um padrão de vida digno em favor de si e de seus dependentes; por outro lado, o credor tem direito ao recebimento de tutela jurisdicional capaz de dar efetividade, na medida do possível e do proporcional, a seus direitos materiais; c) o processo civil em geral, nele incluída a execução civil, é orientado pela boa-fé que deve reger o comportamento dos sujeitos processuais, de modo que embora o executado tenha o direito de não sofrer atos executivos que importem violação à sua dignidade e à de sua 
família, não lhe é dado abusar dessa diretriz com o fim de impedir injustificadamente a efetivação do direito material do exequente; d) só se revela necessária, adequada, proporcional e justificada a impenhorabilidade daquela parte do patrimônio do devedor que seja efetivamente necessária à manutenção de sua dignidade e da de seus dependentes; e e) a regra geral da impenhorabilidade de salários, vencimentos, proventos etc. (art. 833, IV, do CPC/2015), pode ser excepcionada quando for preservado percentual de tais verbas capaz de dar guarida à dignidade do devedor e de sua família.

Diante da relativização que o STJ operou na impenhorabilidade dos vencimentos afastando o caráter cogente da impenhorabilidade legal -, fica difícil sustentar que não possam as partes, convencionar sobre a penhorabilidade do salário do devedor, afastando a vedação do art. 833, VI, do CPC, e fixando uma renda mínima/suficiente para que o devedor possa se manter, alcançando a execução tudo o que demais sobejar.

Entendimento, aliás, que é reforçado pelo fato de que, mesmo antes do entendimento pretoriano supra indicado, já havia no Brasil legislação específica (Lei n. 10.820/2003, com a alteração pela Lei 13.172/2015, e na forma do Decreto 4.840/2003), a autorizar o comprometimento de 30 a $35 \%$ dos vencimentos do devedor para pagamento de empréstimos, financiamentos e operações de arrendamento mercantil.

Ora, se há possibilidade de disposição voluntária pelo devedor de parte do salário para o pagamento das obrigações retro listadas (o que prova que não se trata de regramento cogente), não se vê razão lógica para que esteja vedada convenção processual de penhorabilidade para outros tipos de obrigação, conforme autorização do art. 190 do CPC.

A vulnerabilidade do devedor, a inserção abusiva em contrato de adesão ou o multiendividamento - que podem comprometer a preservação da autonomia da vontade ou a subsistência do devedor-, devem ser analisadas casuisticamente, quando da decisão judicial a respeito da aplicação da convenção processual, não havendo, portanto, vedação prima facie para a admissão da convenção de penhorabilidade parcial do salário.

Até porque - sobrelevar notar -, a disposição de parte dos rendimentos como garantia (penhora) da satisfação de suas obrigações, pode ser algo desejado e vantajoso para o próprio devedor, que diante do menor risco de inadimplemento, acaba por obter as já referidas vantagens de direito material na concessão do crédito e na forma de remuneração (juros) e pagamento (parcelamento). 
Poderia se objetar - como certamente se fará -, que o afastamento da impenhorabilidade por convenção, para além das hipóteses legais, implica prejuízo à família do executado, já que será afetada pelo ato de disposição dele. Afinal, a impenhorabilidade do rendimentos do art. 833, IV, do CPC, pela própria disposição legal, serve à proteção não só do sustento do executado, mas também de sua família. Por isso, não deveria ser cabível a convenção, já que o devedor não teria capacidade de disposição, na medida em que avençaria sobre o que não é (somente) "seu”, violando, assim, o art. 104, I do CC e o o art. 190, caput, do CPC (vide item 2.1. supra).

A correta vedação de convenções sobre situações jurídicas alheias, contudo, não parece ser óbice suficiente para a admissão da convenção de relativização da impenhorabilidade do art. 833, IV, do CPC. Primeiro, porque, na esteira do precedente qualificado do STJ e já citadas leis que admitem o empréstimo consignado em folha, a penhora não poderá recair sobre a totalidade dos rendimentos do devedor, sendo obrigatória a preservação, assim, de parcela que seja suficiente para a provisão do devedor e da família (preservada, portanto, a proteção da dignidade e sustento do núcleo). E segundo, porque como esta é uma daquelas convenções que só se operacionaliza no processo (com o juiz determinando a penhora à luz da convenção), há um permanente controle da validade da convenção, inclusive à luz da capacidade financeira do devedor (cujos ganhos podem variar no tempo, ensejando ampliação/redução da garantia) e necessidade do núcleo familiar (em que gastos extraordinários podem impor a necessidade de revisão do percentual da penhora salarial admitido na convenção).

\subsection{Convenções processuais sobre o bem de família legal}

$\mathrm{O}$ art. $1^{\circ}$ da Lei n. 8009/90 estabelece que "o imóvel residencial próprio do casal, ou da entidade familiar, é impenhorável e não responderá por qualquer tipo de dívida civil, comercial, fiscal, previdenciária ou de outra natureza, contraída pelos cônjuges ou pelos pais ou filhos que sejam seus proprietários e nele residam, salvo nas hipóteses previstas nesta lei".

O parágrafo único da disposição ainda acrescenta que “a impenhorabilidade compreende o imóvel sobre o qual se assentam a construção, as plantações, as benfeitorias 
de qualquer natureza e todos os equipamentos, inclusive os de uso profissional, ou móveis que guarnecem a casa, desde que quitados".

A disposição tem nítido escopo humanitário, de preservar das investidas dos credores o imóvel familiar e seus utensílios, garantindo-se, assim, que o executado e sua família, mesmo diante da existência da dívida inadimplida por um de seus titulares, mantenha a propriedade/posse sobre tais bens e não seja, literalmente, expulsos do lar.

Insta considerar, ainda, que o art. $6^{\circ}$ da Constituição Federal reconhece o direito à moradia como direito social, o que acaba por justificar, ainda com maior afinco, a proteção legal ao bem de família, na forma da Lei 8.009/90.

Por evidente, como toda regra protetiva, a própria lei n. 8.009/90 excepciona a impenhorabilidade (art. $3^{\circ}$ ), estabelecendo que será possível a penhora do bem de família (imóvel e utensílios), se a execução (cumprimento de sentença) for movida: a) pelo titular do crédito decorrente do financiamento destinado à construção ou à aquisição do imóvel, no limite dos créditos e acréscimos constituídos em função do respectivo contrato; b) pelo credor da pensão alimentícia, resguardados os direitos, sobre o bem, do seu coproprietário que, com o devedor, integre união estável ou conjugal, observadas as hipóteses em que ambos responderão pela dívida; c) para cobrança de impostos, predial ou territorial, taxas e contribuições devidas em função do imóvel familiar; d) para execução de hipoteca sobre o imóvel oferecido como garantia real pelo casal ou pela entidade familiar; e) por ter sido adquirido com produto de crime ou para execução de sentença penal condenatória a ressarcimento, indenização ou perdimento de bens; e f) por obrigação decorrente de fiança concedida em contrato de locação.

Do mesmo modo que se faz quanto à impenhorabilidade salarial (art. 833, IV, do CPC), discute-se se seria possível convenção processual sobre as disposições da Lei 8.009/90, seja para ampliar seu espectro protetivo, seja para afastá-lo.

Parece não haver dúvida de que as partes, à luz do art. 190 do CPC, podem ampliar a proteção do bem de família legal, criando paralelamente à proteção legal da Lei 8.009/90, hipóteses de bem de família convencional, como tal, vedada a constrição patrimonial sobre eles.

Possível, assim, que por convenção pré-processual ou processual, credor e devedor excluam da responsabilidade patrimonial do art. 789 do CPC, determinados bens que, a 
rigor, seriam penhoráveis, mas que por questões sentimentais ou familiares, as partes não desejam que sejam constritos (uma joia, uma chácara de recreio, um veículo de colecionador, etc.).

Já quanto à possibilidade de as partes, por convenção, afastar a proteção legal da Lei 8.009/90, inicialmente é importante frisar que a proteção legal não é ao devedor, antes sendo dele e da sua família, como a própria semântica da expressão "bem de família” já indicia.

Em outras palavras, o mote da Lei 8.009/90 é proteger a família da conduta do próprio devedor, que mesmo tendo assumindo legal e voluntariamente obrigações que não foi capaz de cumprir, não verá o seu patrimônio mínimo (da família) - isto é, a casa de morada e os seus utensílios ordinários -, atingido pelo débito de um de seus componentes, ainda que os bens estejam registrados ou sejam formalmente de propriedade dele.

Dito isso, não será possível que o devedor que figure como titular do bem protegido pela Lei 8.009/90, disponha, ainda que consciente de sua conduta, sobre os bens de família na forma do art. $1^{\circ}$ e parágrafo único da citada lei, pois na verdade lhe falta capacidade para o ato de disposição, nos termos do item 2.1., supra. Na medida em que a situação jurídica não é de sua titularidade, mas sim da família, a convenção processual nesse sentido, ressalvada a exceção do art. $3^{\circ}$, VII da Lei 8.009/90 (por obrigação decorrente de fiança concedida em contrato de locação), é nula e, como tal, deve ser reconhecida pelo juiz quando reclamada a penhora do bem de família pelo credor, no curso da execução civil forçada.

A possibilidade de alienação voluntária do bem de família legal pelo titular não parece, sempre respeitado o entendimento em contrário, fator determinante para justificar a validade da convenção processual ora tratada. $\mathrm{O}$ ato de disposição extrajudicial do bem, regulado pelo direito material, guarda singularidades próprias distintas do ato de disposição da proteção legal processual, que protege a família do devedor contra o seu próprio ato de disposição do bem para garantia da obrigação (algo com o que não se preocupa o direito material). Uma coisa é o próprio devedor, voluntariamente, dispor do bem seu. Outra bem diferente é o devedor, contra sua vontade (ainda que tenha dado o bem em garantia), ver o bem expropriado judicialmente em prejuízo da proteção processual que não é só sua (é também da família).

Ao dispensar a proteção legal do bem de família por convenção processual atípica, o devedor poderá obter benefícios de direito material, como a própria facilitação da concessão 
do crédito, redução do custo da operação (juros menores) e ampliação do prazo para pagamento. O que nos leva à afirmação de que, com a admissão de que, oportunamente, o Judiciário não reconheça a validade da avença sob a ótica da falta de titularidade do ato de disposição (que é da família), o devedor acabará por ser indevidamente beneficiado com a convenção frustrada. Pontue-se, todavia, que, o credor também deve ter compreensão do sistema jurídico e dos limites (expostos no item 2 supra) sobre as convenções processuais, de modo que deverá arcar com as consequências de ter participado de avença com quem não podia, ao menos sozinho, celebrá-la. Abusos do devedor, em eventual violação aos postulados da boa-fé material (art. 422 do CC) e processual (art. $5^{\circ}$ do CPC), devem ser tratados casuisticamente para permitirem solução processual diversa (penhora do bem de família), preservando a regra geral aqui posta para os casos padrão.

Dentro da mesma ótica, é possível a renúncia à proteção do bem de família legal, via convenção processual atípica (art. 190 do CPC), se ao ato de disposição compareça toda a família do devedor, que consigo aceite abrir mão da proteção legal. Nesse caso, preserva-se a autonomia da vontade e resolve-se o óbice da titularidade do bem/direito cuja convenção pretende ser celebrada, consequentemente afastando a vedação à penhorabilidade, mesmo fora da exceção do art. $3^{\circ}$, VII, da Lei 8.009/90 (por obrigação decorrente de fiança concedida em contrato de locação).

Observe-se que aqui a solução é parcialmente diversa da lançada no item 4.3 supra, quando se afirmou ser possível convenção processual para admitir a penhorabilidade de parcela da remuneração do devedor, afastando a proteção legal do art. 833, IV, do CP. Embora a proteção aos rendimentos do devedor também sejam de interesse da família, lá a preservação de uma parte da renda do executado, em princípio, seria suficiente para garantia a proteção dela (com o juiz controlando a proporcionalidade da convenção conforme o caso). Aqui não há como se admitir apenas a penhorabilidade de "parcela" do bem de família para protegê-la (especialmente do imóvel). Não há como se deferir a penhora sobre a parcela que caberia ao devedor no bem de família, porque, de todo modo, o bem seria eventualmente expropriado pela sua totalidade (vide art. 843 do CPC), em prejuízo à família (que pode não conseguir adquirir outro bem de família com a parcela que lhe sobejará). Pelo que se faz necessária a presença de toda a família, como parte da convenção, para que ela tenha plenos efeitos contra todos. 
Para aferição dos integrantes da família (consorte, filhos, irmãos, genitores, progenitores, tios/tias etc.), deve haver investigação social ao tempo da celebração da convenção, considerando-se exclusivamente referido grupo familiar ao tempo da avença. Componentes que venham integrar o grupo posteriormente, já passam a gozar da proteção legal do bem de família com a ressalva da convenção processual avençada por todos os ocupantes do grupo familiar que titulariza a proteção, de modo que não será possível ao novo membro do grupo opor a invalidade do negócio processual, se ao tempo de sua celebração não titularizava a proteção legal.

Por outro lado, se na família do devedor houver pessoa incapazes (filhos menores de idade, deficientes etc.), sempre será vedada convenção processual sobre o bem de família. Nestes casos, embora todos eventualmente compareçam ao ato a fim de renunciar à proteção legal do art. $1^{\circ}$ da Lei 8.009/90, a convenção será inválida à luz do art. 190, caput, do CPC, já que celebrada e em manifestou prejuízo de pessoa que não era plenamente capaz, ainda que representada/assistida por quem quer que seja (vide item 2.6 supra).

Isso porque - como todo negócio processual -, a convenção de renúncia à impenhorabilidade do bem de família legal fica sujeita a controle judicial oficioso (art. 190, parágrafo, CPC), inclusive para fins de aferição de eventual nulidade ou vulnerabilidade do devedor ou de sua família, quando da pactuação. Havendo vício quanto à plenitude da capacidade das partes celebrantes (como no caso de participação de incapaz na convenção), ou mesmo, nos casos de partes capazes, indicativos de vício de consentimento (ausência de autonomia de vontade), o juiz deve negar a aplicação da convenção e vedar a penhora do

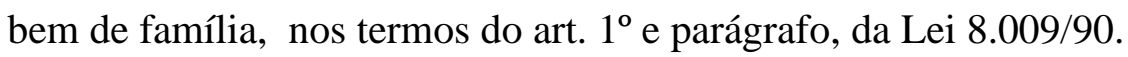

\begin{abstract}
"Os atos de disposição ou convencionais não podem prejudicar terceiros, ou seja, pessoas que não participam da relação jurídica processual e, caso isso aconteça, caberá o imediato controle judicial, de ofício ou por provocação do interessado" (...) "eventuais acordos formulados pelas partes que afetem incapazes não integrantes da relação processual também deverão ser limitados"25.
\end{abstract}

Portanto, na esteira das condicionantes do item 2 supra, dois fatores são determinantes para definir a possibilidade de convenção processual atípica, na forma do art. 190 do CPC, para admitir a penhora do bem de família legal (art. $1^{\circ}$ da Lei 8.009/90).

\footnotetext{
${ }^{25}$ CABRAL, Trícia Navarro Xavier. Limites da liberdade processual. Indaiatuba/SP: Foco, 2019, p. 146/147.
} 
Primeiro, como pressuposto positivo, toda a família deve, expressamente, aderir a convenção, afastando o óbice da ausência de titularidade do ato de disposição (ainda que a obrigação seja, apenas, de um dos seus componentes). E segundo, como pressuposto negativo, não pode haver incapazes na família, caso em que há vedação legal expressa à convenção (art. 190, caput, do CPC).

Não é difícil compreender que, às considerações aqui postas, deve ser ressalvar a possibilidade de penhora do bem de família do fiador em contrato de locação residencial, na forma do art. $3^{\circ}$, VII, da Lei 8.009/90. Aliás, nesse caso nem convenção processual para a admissão da penhora do bem de família do fiador será necessária, já que para a cobrança do crédito desta natureza NÃO há proteção legal do bem de família e, por isso, é perfeitamente penhorável o imóvel domiciliar do fiador (ainda que único), seja o núcleo familiar composto por ele ou por filhos incapazes (!).

Prevaleceu o entendimento, no STF de que a voluntariedade na prestação da garantia pessoal (fiança) implica renúncia à proteção da Lei 8.009/90, não havendo incompatibilidade alguma do art. $3^{\circ}$, VIII, da Lei 8009/90, com o direito constitucional à moradia do art. $6^{\circ}$ da CF (Tema 295 de Repercussão Geral). Buscou-se, com isso, prestigiar-se a boa-fé das partes envolvidas (que voluntariamente prestaram e receberam a fiança), bem como incentivar a prática da locação residencial de imóveis (já que o credor, nos teremos da lei e da jurisprudência do Supremo, tem uma "super garantia" de pagamento nos casos em que prestada fiança).

Há, contudo, sinais de que o entendimento retro apresentado do STF pode sofrer mudanças (antecipatory overruling).

Embora o precedente firmado em 2010, no tema 295 da repercussão geral, tenha se dado no plenário virtual do Supremo, mais recentemente, em junho de 2018, a $1^{\text {a }}$ Turma do STF, por maioria de votos, declarou a incompatibilidade da penhora do bem de família do fiador, dado como garantia em contrato de locação comercial, frente ao direito constitucional à moradia (art. $6^{\circ}$ da CF). Declarou-se que a previsão do art. $3^{\circ}$, VII, da lei 8.009/90, que permite a penhora de bem de família para satisfazer fiança concedida em contrato de locação, não abrange os contratos de locação comercial (RE 605.709/SP, Rel. p/acórdão Min. Rosa Weber). Como não há na Lei 8.009/90 (art. $3^{\circ}$, VII), distinção entre fiança em locação comercial ou residencial, parece haver sinalização de que se o tema, se voltar ao plenário da 
corte, pode ser alterado em prol da tese da invalidade da penhora do bem de família do fiador, ainda que a garantia tenha sido prestada em contrato de locação residencial ou comercial.

Crê-se, de lege ferenda, que a melhor solução para o problema do art. $3^{\circ}$, VII, da Lei 8.009/90, seria a revogação do dispositivo, para que a penhorabilidade do bem de família do fiador, em contratos de locação (comercial ou residencial), eventualmente fosse objeto de convenção processual atípica, na forma do art. 190 do CPC. Com isso, privilegiada estaria a autonomia de vontade das partes (locador e fiador), bem como se resolveria a questão da proteção legal dos incapazes que titularizam o bem de família, protegidos que estariam pelo inadimplemento das obrigações de seus provedores, nos casos em que figurassem como fiadores em contrato de locação.

\section{Conclusão}

O tema das convenções processuais atípicas, por si só, é novo no Brasil. A disciplina legal sobre o tema veio apenas com o CPC/2015. São inúmeras as dúvidas e inquietações que afligem todos os operadores do Direito.

Ao inserir a temática no âmbito da execução civil - espaço que, quase sempre, foi reservado à atuação estatal a partir de lei em sentido estrito (inclusive em vista da natureza coativa/forçada da atuação judicial) -, multiplicam-se os problemas técnicos e práticos, inclusive pela parca atenção que, ainda, é dada pela doutrina e jurisprudência a respeito.

A impressão que se tem é que são tamanhas as dúvidas e dificuldades sobre a possibilidade e limites das convenções processuais em matéria de execução civil, que partes e advogados preferem não negociar a respeito, relegando à reserva legal o regramento do processo e do procedimento executivos.

Não temos dúvida, contudo, que há um enorme espaço para os negócios processuais no âmbito do cumprimento de sentença e da execução de título extrajudicial, que se preenchido adequadamente pelas partes, pode propiciar não só um processo mais aderente à realidade econômica/financeira dos envolvidos, mas aumentar, exponencialmente, a efetividade do processo de execução e a possibilidade de satisfação das obrigações.

O importante é termos em mente sempre, duas ponderações. 
Primeiro, se de um lado, deve sempre ser preservada a dignidade do devedor, por outro, a efetividade da execução e o respeito à autonomia da vontade das partes não são valores que podem, simplesmente, ser desconsiderados na equação.

E, segundo, as respostas sobre a possibilidade/impossibilidade de convenções processuais em matéria de execução civil, especialmente nos 04 (quatro) casos problematizados no texto (convenções sobre extrajudicialização da execução; convenções para incidência de medidas executivas atípicas em caso de inadimplemento; convenções de penhora da remuneração do devedor; e convenções sobre a penhorabilidade do bem de família legal), não podem ser obtidas sem a atenta análise das particularidades do caso concreto.

\section{REFERÊNCIAS}

ALVIM, Arruda. Manual de Direito Processual Civil. 19ª ed. São Paulo: RT, 2020.

ANDRADE, Juliana Melazzi. Negócios jurídicos processuais na execução fiscal. In: Negócios processuais - tomo 2 (coordenadores Antonio do Passo Cabral e Pedro Henrique Nogueira). Salvador: Juspodvm, p. 569-587.

ANGIONI, Enrica. Negozio giuridico processuale e categoria generale di contratto nella scienza iuridica europea. Dottorato di ricerca, Università degli Studi di Cagliari, $2014 / 2015$.

BORGES, Marcus Vinicius Motter. Medidas coercitivas atípicas nas execuções pecuniárias. São Paulo: RT, 2019

CABRAL, Antonio do Passo. Convenções processuais. Tese de livre docência. Faculdade de Direito da USP, 2015.

CABRAL, Antonio do Passo; DIDIER JR., Fredie. Negócios jurídicos processuais atípicos e execução. Revista do Ministério Público do Rio de Janeiro, n. 67, jan-mar/2018, p. $137 / 165$.

CABRAL, Trícia Navarro Xavier. Limites da liberdade processual. Indaiatuba/SP: Foco, 2019.

CAPONI, Remo. Autonomia privata e processo civile: gli acordi processual. Procedure Review, v. 1, n. 2., p. 42/57, jul-set./2010. 
CARMONA, Carlos Alberto. Arbitragem e processo: um comentário à lei no 9.307/96. $3^{\mathrm{a}}$ ed. São Paulo: Atlas, 2009.

CHIOVENDA, Giuseppe. Instituições de Direito Processual Civil. Traduzido por Paolo Capitano. Campinas: Bookseller, 1998c v. 3.

DINAMARCO, Cândido Rangel. Execução civil. $8^{\mathrm{a}}$ ed. São Paulo: Malheiros, 2002. Instituições de direito processual civil. $3^{\text {a }}$ ED. São Paulo: Malheiros, 2009. vol. 3.

FURTADO, Paulo. O negócio jurídico processual na recuperação judicial. Migalhas. São Paulo. Disponível em: https://www.migalhas.com.br/coluna/insolvencia-emfoco/284720/o-negocio-juridico-processual-na-recuperacao-judicial. Publicado em: 31.07.2018.

GAJARDONI, Fernando da Fonseca; DELlORE, Luiz; ROQUE, Andre Vasconcelos; OLIVEIRA JR., Zulmar Duarte. Teoria Geral do Processo: Comentários ao CPC/2015. $3^{\mathrm{a}}$ ed. São Paulo: Método, 2019.

GAJARDONI, Fernando da Fonseca. Convenções processuais atípicas na execução civil. Gen Jurídico. São Paulo. Disponível em: http://genjuridico.com.br/2017/10/30/convencoes-atipicas-execucao-civil/. Publicado em 30.10.2017.

- A revolução silenciosa da execução por quantia. Jota. Brasília-DF. Disponível em: www.jota.info/opiniao-e-analise/artigos/a-revolucao-silenciosa-daexecucao-por-quantia-24082015. Publicado em: 24.08.2015.

. Flexibilização procedimental: um novo enfoque para o estudo do procedimento em matéria processual. São Paulo: Atlas, 2007.

MACHADO, Marcelo Pacheco. A privatização da técnica processual no projeto do Novo Código de Processo Civil. In: Alexandre Freire et al. Novas tendências do processo civil - estudos sobre o projeto do Novo CPC. Salvador: Juspodvm, 2014, v. 3, p. 339362.

Negócio processual de renúncia à impenhorabilidade. Jota. Brasília. Disponível em: /www.jota.info/opiniao-e-analise/artigos/novo-cpc-e-negocioprocessual-de-renuncia-impenhorabilidade-14112016. Publicado em: 14.11.2016. 
MINAMI, Marcos Youji. Da vedação ao non factibile: uma introdução às medidas executivas atípicas. Salvador: Juspodvm, 2016.

MOREIRA, José Carlos Barbosa. Convenções das partes em matéria processual. Temas de direito processual civil: terceira série. São Paulo, Saraiva, 1984, p. 87/98.

NOGUEIRA, Pedro Henrique. Negócios processuais. $2^{\mathrm{a}}$ ed. Salvador: JusPodivm, 2016.

OLIVEIRA NETO, Olavo. O poder geral de coerção. São Paulo: RT, 2019.

REZENDE, Diogo Assumpção Rezende de. Contratualização do processo. São Paulo: LTr, 2015.

ROCHA, José Albuquerque. Teoria geral do processo. 3ª ed. São Paulo: Malheiros, 1996.

RODOVALHO, Thiago. O necessário diálogo entre doutrina e jurisprudência na concretização da atipicidade dos meios executivos. Jota. Brasília. Disponível em: www.jota.info/opiniao-e-analise/artigos/o-necessario-dialogo-entre-doutrina-ejurisprudencia-na-concretizacao-da-atipicidade-dos-meios-executivos-21092016.

Publicado em: 21.09.2016.

SILVA, Paula Costa e. Pactum de non petendo: exclusão convencional do direito de ação e exclusão convencional da pretensão material. In: CABRAL, Antonio do Passo; NOGUEIRA, Pedro Henrique Pedrosa (Coord.). Negócios processuais. $3^{\mathrm{a}}$ ed. Salvador: JusPodivm, 2017.

SILVA, Renata Rodrigues. Limites dos negócios jurídicos processuais: um estudo sobre o objeto das convenções atípicas. São Paulo: Dialética, 2020.

SILVA, João Paulo Hecker da. Convenções processuais na execução e desjudicialização da atividade satisfativa. In: Direito Bancário (coordenadores Marcio Calil de Assumpção e Gabirel José de Orleans e Bragança. São Paulo: Quartier Latin, 2018, p. 161/193.

TEMER, Sofia; ANDRADE, Juliana Melazzi. Convenções processuais na execução: modificação consensual das regras relativa à penhora, avaliação e expropriação de bens. In: Coletânea mulheres no processo civil brasileiro - negócios processuais (Coordenadores Ana Marcato et al). Salvador: Juspodvm, 2018, p. 551-567.

TUCCI, José Rogério Cruz e; AZEVEDO, Luiz Carlos de. Lições de história do processo civil romano. São Paulo: RT, 2001. 
VOGT, Fernanda Costa. A tomada do procedimento pela vontade: as convenções processuais e o princípio da atipicidade na execução civil. Civil Procedure Review, v. 10, n.3, p. 171/191, set-dez/2019.

YARSHELL, Flávio Luiz. Tutela jurisdicional. 2a ed. São Paulo: DPJ, 2006.

Convenções das partes em matéria processual: rumo a uma nova era? In: CABRAL, Antonio do Passo; NOGUEIRA, Pedro Henrique Pedrosa (Coord.). Negócios processuais. $3^{\text {a }}$ ed. Salvador: JusPodivm, 2017. 